\title{
Africa in Brathwaite: The matrix of cultural quest, identity and history as poetic vision
}

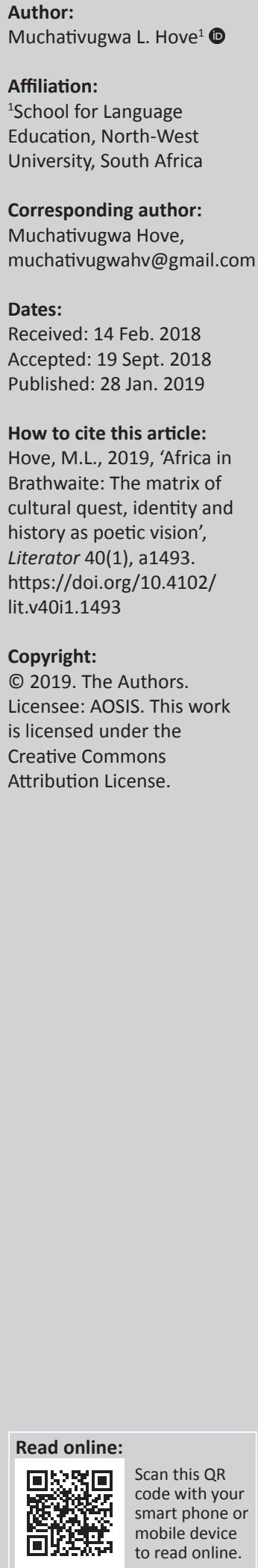

Brathwaite's invocation and experimental appropriation of 'nation language' is a significant mediation that destabilises and de-authorises coloniality, inscribing a new 'in-betweenness' that highlights how the subaltern can speak. I argue here that the poet-persona's minted vocabulary and his re-appropriation of canonical texts such as the Bible and Shakespeare's The Tempest inaugurates a meta-discursive enunciation of epistemic possibilities. In embracing the fragmented contours of Barbados and radically privileging the political complicity of Africa in the matrix of slavery, Brathwaite embosses languaging as the primus for problematising identity, belonging and becoming. Polysemy therefore emerges as a complex interplay of enunciation and emergence, agency, subjectivity and restlessness that recuperates the anguish of contact, marginality and resistance while at the same time celebrating the plurality of the interstitial self.

\section{Origins and author(ity): Naming and the topos of (un)naming in Brathwaite}

Born Edward Brathwaite in 1930 in Barbados, he read History at Cambridge and subsequently taught History in Ghana (1955-1962), making his 'relocation' to Africa and the first intimate encounter with the 'paradoxical ancestral continent' (Brathwaite 1973). A long-standing friendship with the Kenyan writer Ngugi wa Thiong'o saw him stay in Limuru, Kenya, where Ngugi's mother named him Kamau (literally, my son) - a name that he has continued to use since then. Curious and committed to explore his 'tricontinental identity' ('the three-souled Carib' of Aime Cesaire in Return to My Native Land [2014]), Brathwaite has deliberately patterned his poetry as trilogies. The first, collectively entitled The Arrivants, includes 'Rites of Passage', 'Islands' and 'Masks'. The latest begins with Mother Poem (Brathwaite 1977) whose sequel is Sun Poem (Brathwaite 1992), and this culminates in X/Self (Brathwaite 1987). In X/Self, he moves further to reclaim a fourth tributary to his identity (the Maroon), and the four landscapes (African, European, American and AmerindianMaroon) cross-fertilise each other to create a poetically complex, experimental, questing, restless and assertive Caribbean voice. It is interesting that the $X / S$ elf sheaf of poems textualises the ' $X$ ' as both a vexed symbol of ambiguity, indeterminacy, mysterious precision and paradoxical name, the former and the present, surreptitiously laying claim to both the past and the present. ' $\mathrm{X}$ ' suggests, concurrently, power and namelessness, a collocation of the 'in-between' and the outside, that strange phenomenon Homi Bhabha (1990) aptly describes as 'almost-but-not-quite'.

Brathwaite is both rational and emotional in the (trans)fusion of verbal and musical forms into poetic ones. This article interrogates spatial practice, representations of space and representational spaces as significant preoccupations in Brathwaite's long poems. These three categories of spatial interaction become, respectively, present to the individual subject as the 'perceived-conceivedlived' triad or, in reverse order, as the lived, conceived and perceived realms. Barbados and Africa provide both the locus and continuum through which Brathwaite inaugurates a narrative, discursive and poetic polysemantic 'nation languaging' project that seeks to subvert the colonising one. The long poem etched in The Arrivants, Mother Poem, Sun Poem and X/Self destabilises power and linguistic configurations that results in several semantic challenges and possibilities. Along a continuum that defies semantic closure, Brathwaite appropriates and deploys extensive troping, textual annotation and commentary, innovatory experimentation, highly metaphorical, metonymical and figurative language, a strong presence of ellipsis, rhythmical, syntactical and typological irregularities.

Through the tensions of folk rhythm, historical flashbacks and poetic-cum-imaginative excursions to Europe, New York and Africa, Brathwaite garners new perspectives and expresses a portentous vision. He locates Barbados and the West Indies in the context of global power dialectics and the 
concept of minorities: the brutality of slavery and colonial imposition; expression of discontent not only with coloniality but with the attempts to legitimise the order of mass culture. Mass culture took manifold expressions: in Jamaica the Reggae/Rasta combination; in Trinidad the Kaiso/Steel Band experience and Carnival in other parts of the Caribbean. The bands, the masquerades, the spectacle and the unforgettable collage of psychedelic colours are incorporated into the artefacts of V.S. Naipaul, Abel Mittlleholzer, Derek Walcott, George Campbell, Lindsay Barrett - and Brathwaite blends these with his poetry to chronicle a vision of commitment to change through 'nation language'. Nation language, Brathwaite argues, embodies 'the force of the hurricane' and 'ignores the pentameter' in its contours, its rhythm and timbre, and its sound explosions. To that extent then, nation language, which Brathwaite creates, adapts and deploys in the fashion of Amiri Baraka (aka Mutabaruka), is not English. He was later to submit that 'it is not language, but people, who make revolutions'. I submit therefore that Brathwaite inaugurates nation language by focusing on environmental expression, nommo and groundation in Mother Poem. In the sequel, Sun Poem, he deals with caned space, dominated and appropriated space, while in X/Self, he delves into counterspace.

\section{Recuperating Caliban and rhetorical tropes of ambivalence}

Brathwaite, perhaps more than Derek Walcott, explores 'nation language' through the economy and philosophical mischief of puns, the solace of allusion and the celebratory power of metaphor ('Barbados, my mother, is porous limestone' - Mother Poem [Brathwaite 1977]). Where Walcott imitated the tradition of established and canonical western poets (William Shakespeare, John Milton, Alexander Pope and Gerard Manley Hopkins), using poetry in its structured form to explore the manifold aspects of life around him (West Indian history, politics, landscape, the nature of memory and of the creative imagination), telescoping 'time' and displaying a consuming predilection for the iambic pentameter, Brathwaite adopted an atypical vers libre to explore the fragmented and dislocated Caribbean psyche and personality. Gordon Rohlehr (1983) sees 'Masks' as:

An epic poem about the lost kingdoms of Africa (Akum, Meroe, Mesopotamia, Ouagadougou, Timbuktu, Ashanti, Volta ...) elegiac and grave in tone ... 'Masks' seeks reasons why the tribes of Africa disintegrated; [it] seeks positives and asks what did the African create in spite of all; how did he transcend the cycle of journey, arrival, disaster and further journey (p. 340).

The most arresting and enduring quality in Brathwaite is his assertion of identity as a Jamaican, together with the realisation that that identity as a historical confluence of African tributaries conflated by the 'Black Atlantic's Middle Passage'. Further, the 'deracinated black' has other faces as the pathetic Uncle Tom, broken by the whip on the sugarcane plantations and the dilettante who loses self and soul by acting out the role prescribed for him by the paternalistic white world. An unwavering quest for the meaning of the harsh logic [that] guides [our] story ('All God's Chillun' [p. 21]) leads Brathwaite to assert:

Muh ol' arrivance is from Africa ... That's muh ol' arrivants family. Muh gran'muddah an' muh gran'fadda ... they came out here as slavely ... when they came now, I doan belongs to Africa, I belongs to Jamaica ... So I just travel right up to hey, an' gradually come up, an' gradually come up, until I experience all about ... the African set up ([Preface to The Arrivants] Brathwaite 1973:xii).

The journey to Africa is at once a physical, emotional, historical landmark and a therapeutic excursus to an Africa that is historically and metaphorically the persona's cultural cradle. There is no idyllic romanticisation of the kingdoms of Africa in Brathwaite, though it is important to note that the history and memories of Africa's glorious achievements are a contemporary counterbalance to the persona's experiences of the worst in the west (Vinson 1983).

Brathwaite therefore lays claim to a languaging practice in the long poems that is deliberately framed by a confrontational agenda, the 'nation language' that he espouses as providing a platform for 'total expression':

... nation language, which is the kind of English spoken by the people who were brought to the Caribbean, not the official English now, but [Bajan] the language of slaves and labourers, the servants who were brought in by the conquistadors. (Brathwaite 1984:298)

The combination of kumina, shango, kaiso, carnival, calypso, reggae and robber talk all make 'nation language' an encyclopaedic repertoire replete with massive possibilities. This assemblage is privileged because Brathwaite recognises that 'the hurricane does not roar in pentameter. And that's the problem: how do you get a rhythm that approximates the natural experience, the environmental experience?' (Brathwaite 1986:17).

'Masks' shows an Africa that teems with game - 'lion, leopard, elephant' and natural, life-sustaining courses in the Congo and the 'watering Niger', a land of refined cultures bursting with 'dancers, the flutes, reed voices ... [and] the songs' achievement of cymbals' (p. 104). The persona affirms that there shall be 'no peace in this world' till the soul know 'this (Lake Chad) dark water's world' (p. 105), where man and the teeming game of the world live in a romanticised and peaceful co-existence. In 'Timbuktu', the 'golden age' of free trade where camels transported gold across the desert, the civilisation of education and Islamic religion (aptly recaptured and recreated in D.T. Niane's Sundiata, an Epic of Old Mali) has 'returned again to dust'. Africa's own people have contributed to the demise of these empires and archives, and an itching nostalgia remains to gnaw at the persona's wretched being in 'Volta':

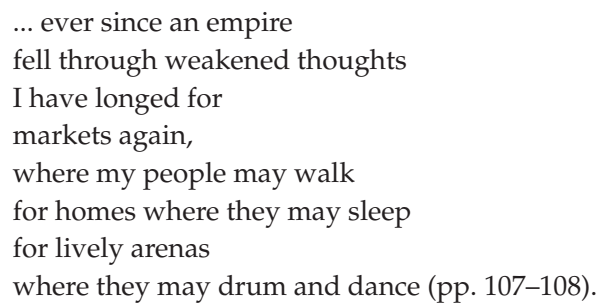


The sense of being unhomed is traceable to Africa inasmuch as its locus is also the Caribbean experience. The drum - so central a symbol in 'Masks' - becomes an expression of selfhood and ritual, a source of musical rhythm metonymic of inner rhythm and the pulse of communion across the seas between the African hinterland and the diasporic.

'Limits', in the journey across Africa, hinges on the physical impediments of the forest where 'no pathway showed

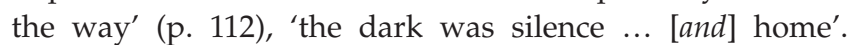
The persona and fellow sojourners clear a piece of the land, light a fire to scare the dangers of the night and 'in unison sang of warmth ... bodies touching', but disappointingly they discover that the imperial glory of the past has been saddled by a new enigma:

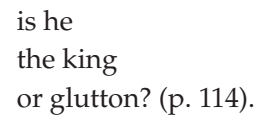

The 20th century African leadership 'lives on human blood/ and dies in human blood': in the new political economy, it is the 'frogs only [that] wear jewels' ([The Arrivants] Brathwaite 1973:115). '[T]he desert drifts certainties outside up' and 'man eats god, eats life, eats world, eats wickedness' (p. 115). However, Brathwaite does not allow the subjective pessimism evident here to blur the trajectory of a humanising possibility born out of collective effort and sheer determination. He asserts that even if in Africa, 'dark roots of time move in our way to trip us, we [shall] continue to dance' (p. 116). Indeed, Ananse's 'tuneless trap of doom' (p. 119) shall be overcome because 'the way lost/is a way to be found again' - an affirmation of the possibilities of rehabilitation for the children of the diaspora akin to Ayi Kweyi Armah's vision of 'the way' in Two Thousand Seasons.

The traverse from one African civilisation to another African civilisation - long, arduous, purifying, experiential and apocalyptic in its revelation of the intrigue - has its terminus ad quem in the 'minutes of pebbles/dropping into the hourless pool' of 'The White River'. Brathwaite here again harnesses the power of pun and metaphor to locate the point of departure of the restless persona when the whites (White River) 'nudged us like fish' into the 'slave ships at Elmina'. Elmina is the slave port on the coast of Ghana where captured bodies were driven into the shipping dungeons to Toubob land. Not knowing what awaited them on the slave ships, Elmina literally hounded the slave captives in its dungeons. They were subjected to grotesque indignities, torture and humiliation. Thus, the returnee to Africa, discovering the desolateness of ancestral Africa and relating it to the 'porosity of Barbados', powerfully laments:

\footnotetext{
O! New world of want

who will build the new ways

The new ships? (p. 122)
}

to sail towards a humanised beginning. There are no easy answers and no immediate solutions. In the portrait of the new arrivant, (solemnised in 'akwaaba'/welcome) who is received after 300 years, offered a stool, water to wash his hands and plantain to eat, we see how the arrivant bears the question 'whose ancestor am I?' (p. 125) remaining perturbed, intensely becoming fragile in 'whose brother am I now?' (p. 126).

The 1972 plaque erected at Elmina uncannily recreates the dystopic and enigmatic significance of the fort, especially that sinister 'door to doom', also called the 'door of no return':

In everlasting memory of the anguish of our ancestors

May those who died rest in peace

May those who return find their roots

May humanity never again perpetrate such injustice against humanity

We, the living, vow to uphold this.

Brathwaite, as one who returns to find his roots in Ghana, does not falter to exploit the irony implicit in 'akwaaba' - an Akan welcome greeting which was historically extended to slaves who viciously violated their welcome by capturing the host. Mugo wa Kebiro's prophecy in Ngugi wa Thiong'o's The River Between - 'beware the butterflies, beware the white man' - is aptly captured in his Akyere counterparts' warning, 'Beware ... do not trust strangers' (Brathwaite 1973:127). The hospitality of Africa is seen as a double-edged sword, turned against the wielder to decimate his lineage through slavery. That 'error in history' is compensated for in 'The Awakening' where the persona reassures the reader that:

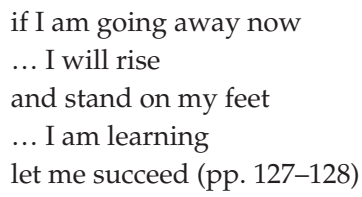

Learning to stand, to succeed and to 'become' are processes that are founded on hope and faith - not despair. Becoming, according to Masemola (2017:41), by virtue of its limitless islands of time, provides the opportunity for a retrospective contemplativeness that radicalises memory. The journey to Africa has secured the persona's roots and dispelled the myth perpetuated by Eurocentric scholarship and racism that:

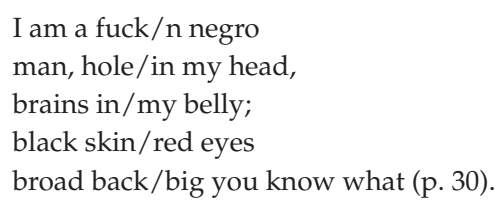

Brathwaite's awakening here echoes that of Aime Césaire whose persona 'at the brink of dawn' begins to question '... who twists my voice? who scratches my voice?' ([Return to My Native Land] Césaire 2014:97). Bearing the beacon of hope enshrined in journeying and learning, the persona in Brathwaite has mined memories of the African past, the sodomies of the triangular voyage and the indelible fingerprints in cane and cotton fields to shape the links and continuities of self and society. The new-found brotherhood whose common features are bitterness and determination poetically salvages and celebrates black as the paradoxical colour in which life and creativity inhere: blackness conjures 
both the beautiful and the problematic. The tom-toms, the rhythm of the drums and the heroic achievements of Africa are all harnessed towards a new beginning and re-evaluation of the role of this African heritage in the experience of the Barbadian and the Caribbean. In the experience of the persona in Brathwaite, and especially the voyaging across the black Atlantic (Gilroy [1993]1999), the diaspora has no settled culture (Masemola 2017:34).

Education, particularly in history and literature, has virtually rendered the Barbadian 'leaderless, heroless' as the students of 'Chalkstick the teacher' ([Mother Poem] Brathwaite 1977:19) are taught that they have 'created nothing' and they are made to see 'Cortez, Drake and Christopher Columbus and Ferdinand Magellan' as 'discoverers' of the new world (p. 73). The epic journey to Africa therefore has to be seen as a self-education process which shall nurture a new consciousness that accords heroic status to 'Louis Armstrong with his blues' (p. 32), Toussaint L'Overture and the Haitian revolution (p. 36), recognising the therapeutic effect of the 'riots in Brixton' (p. 40) and taking national pride in the Creole language which he defends as 'nation language' (Brathwaite 1984).

This re-orientation that has been purposefully navigated serves to infuse a radical departure from the 'timid Tom' who 'yesses' to 'Massa' and 'Baas' and creates instead in 'Negus', the combative returnee to the islands who proclaims:

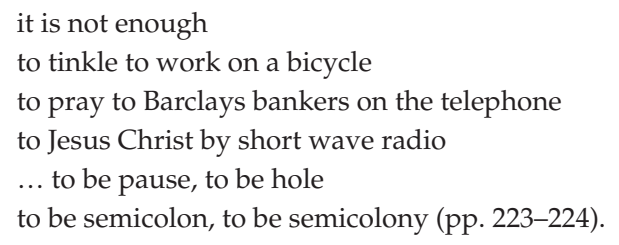

In this instance, isocolonic repetition, onomatopoeic neologisation, concrete chiasmus and extensive halfhomonymical punning are dominant stylisations which together lend to the explosive lyricism of this unique trope a stable but apparently spontaneous structure. Brathwaite discards the space-clearing formality of postcolonial academe and instead throws whole swathes of linguistic territory back to empire in this accomplished performance of rhythm and blues (Thurgar-Dawson 1998:41). The divide and conquer politics of the imperial sonneteers has been replaced by the 'riddim' of total expression.

A radical shift in paradigms is sought through the diasporic circuit, as:

$$
\text { I }
$$

must be given words to shape my name

... words to refashion futures

like a healer's hand (p. 224).

There is an unmistakable pugilist in Brathwaite calling on 'words to shape my name' because this moment of rupture is also a moment of reconnection where the name (nommos and the body) are sites of enunciation, a lamination of past and present, history and future, an assemblage both monumental and problematic. This re-fashioned 'future' accommodates 'Carnival' and 'Ogun', 'Shango' and 'Toussaint L'Overture': cultural archives and historical-ontological tropes of black ethnicity that further the development of a West Indian national consciousness (Campbell 1985) as distinct from the dominion and 'semicolony' status that sees Barbados as 'Little England'. Brathwaite's concerted perception and description of 'Africanisms' as synthetic components of West Indian culture are further extended into integral elements in the successive poems - Mother Poem, Sun Poem and X/Self.

If 'Islands' in The Arrivants (Brathwaite 1973) superbly poeticises the return journey from Africa, Mother Poem (Brathwaite 1977) explores Barbados and its people, 'slavery ... and its effect upon the manscape' ('Preface') and the 'songs that have not forgotten their ancestry of iron' (p. 45). Barbados is symbolically conceived of as a mother/ woman figure, a 'black Sycorax' who:

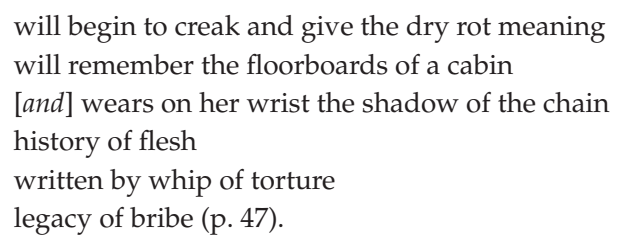

The Barbadian landscape becomes a canvass upon which the poet-persona colours past and present, Europe and Africa, 'catholic bells and kumina' in an effort to make a statement that proclaims 'koumforts' even if the West Indian reality is 'shards, shreds, broken tools, cast off political clothing' (Brathwaite 1977:112). The account of 'this African diaspora' is convincingly and appropriately linked to Caliban's encounter with Prospero. The jagged lines, split words and complex puns that abound in Mother Poem and X/Self are deliberate experiments with 'nation language' in order to historicise the West Indians' loss of their original African languages and their halting learning of curses and epithets, anagrams and holograms as they crisscrossed cultural and linguistic boundaries in the 'great triangular routes'. In a dazzling illustration and reconfiguration of the interplay between memory (history) and the present, Brathwaite envisions Caribbean 'heros' as the African 'Herero' people of whom 'every sperm' was destroyed by the 'germans' but these people regained their manhood by making 'pelmets' out of the skulls of their fallen kinsmen (Brathwaite 1987:77). Regeneration is accomplished and sourced through:

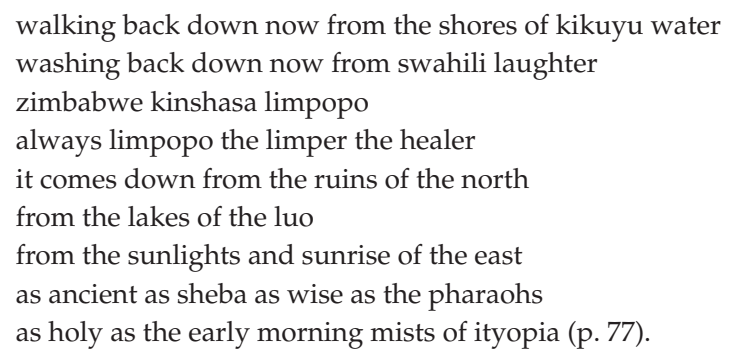

The signs of this regeneration are evident, Brathwaite seems to say, in the cataclysmic assertions of the 'nationhood of Soweto' (p. 78), [queen] 'nzigas' (p. 79), 'learning prospero 
language' (p. 84), 'the peoples' liberation army; (p. 90) - all aimed at destroying 'loan sharks from across the water' (p. 94) who create and perpetuate 'capitalism and slavely' (p. 82). In order that 'we may be cleansed' (p. 98), the persona in X/Self rallies the black diaspora - 'o sisyphus o herculean labourer' (p. 99) - to stand up 'against this history that will not write us up unless we lying down' (p. 101).

Africa then, as would be evident thus far, stands as a unique and ambivalent symbol in Brathwaite's poetry. The 'pyramids of Cheops' and 'Meroe' and 'Zimbabwe' are unparalleled civilisations from which to draw inspiration and pride: zeniths of achievement. Paradoxically, the great betrayal by chiefs and 'factors' in the slave trade are indelible sources of shame, anger, frustration and humiliation. In the millennial struggles for self-rule and self-definition, Africa provides prospects for the Caribbean's quest towards a peak that affirms their identity (Vinson 1983). Prince and peasant, merchant and agriculturalist, warrior and priest: these are Africans drawn into the vortex of the Atlantic slave trade and Brathwaite has each specimen in the poems marshalled into the sugar fields of the 'new world discovered by Columbus'. Re-inscribing historical figures and ancient civilisations in lower case, added to punning and repetitious letterswapping, become manifestations of poetic minting where nametricks emerge as nametracks (Thurgar-Dawson 1998:43). Here, Brathwaite deals almost exclusively with the powers and dangers involved in the process itself of 're-naming,' a process which is ever subject to polysemantic strategies of veiling, disclosing and doubling (Hall 1996) to which his long poems are both particularly suited and justly renowned.

What these arrivants brought in the form of dances, tales, folklore, music, magic (voudon), language, drums, flutes and rhythmic sophistication are all harnessed by the poet-persona to shape a poetry that defies categories such as formal structuration and conventional readings. Ananse the spider - congenitally weak and fragile and looked down upon by all the stronger animals - is brought into Brathwaite's poetry as wise, patient, boastful, mischievous, roguish, cunning and always outwitting its stronger foes. And, as Brathwaite confesses, similar portraits of African 'survivals' replete in the novels of George Lamming (In the castle of my skin) and Jacques Romain (Masters of the dew) have had a lasting influence on how the poet views the 'acculturation' process as an 'Africanisation of the Caribbean'. This survival of varying degrees of African cultural traits and practices in the Caribbean points to those practices whose value and enduring superiority have given them strength and tenacity to do so (Josephs 2003:6) - and Brathwaite sees the resilience and utility of those aspects in contemporary West Indian culture. In the penultimate:

while we sweat/in this tin-trunk'd house [and]

[I have] never seen

a man travel more

than this poor

pathless harbor -

less spade. (Brathwaite 1973:34)
All these are cross-cultural traits and influences that must only be accepted insofar as they assist in rejuvenating a selfconsciousness that appropriates and marshals positive characteristics towards the 'liberated day' whose 'blues will inherit the world' with 'new thing marley, soul, rock' (Brathwaite 1987:110).

Bob Marley's burning question: 'How long shall they kill our prophets/While we stand aside and look?' (Survival, 1978), is integrated into Brathwaite's urgent call for a cultural and linguistic renaissance. And in the Caribbean experiences, voices such as Mutabaruka, Linton Kwesi Johnson and Peter McIntosh have come to the fore in critiquing and battering imperialism's onslaught. The multiple intersections of the word and the world suggest that place is indeed a powerful theatre for memory, especially in the manner in which Brathwaite's generative poetry raises awareness by mobilising conversations thematised by a discursive re-territorialising of 'nation language'.

In conclusion, we realise that Brathwaite uses Africa in his poetry not as a romanticised, idyllic return to the source, à la Amilcar Cabral (1973/1982), but as an ambivalent repository of cultural and historical treasures from which the Caribbean hoi-polloi as a sociological and political ensemble could build and make history. The struggles against foreign domination - targeted at coloniality, racism, imperialism and corporate multi-nationalism deployed as currency in globalisation parlance - are engendered in X/Self, Mother Poem and The Arrivants as therapeutic. In the self-styled splitting of words, clauses, phrases and sentences, Brathwaite mints a novel vocabulary and convinces the reader that this new energy and creativity contributes to a re-imagination of the space for 'black souls' making history (Vettorato 2012). In putting these 'wrecked words' on paper, he fuses, yokes and integrates the African and the Barbadian, often bringing violently together highly improbable combinations that mirror the improbable history of torture and pain:

The lord is my shepherd

He created my black belly sheep (Brathwaite 1977:9).

He parodies Psalm 23 in this instance. In another instance, he bandies Shakespeare's The Tempest:

Ban
Ban
Cal-
iban
like to play
pan
at the Car
nival (Brathwaite 1973:193).

The contemporary Carnival is given to the archetypal symbol of Caliban as a dance of identity, where he hurls curses at Prospero. Brathwaite's poetry is highly allusive and the techniques of hyphenation, repetition and word-smithing/ word splitting become effective devices for temporal, spatial and semantic dislocation. In this re-inscription of Caliban as legitimate owner of the island, the poet enkindles a connection 
to a latter-day contemporary, Mutabaruka (1986), who in The Mystery Unfolds memorably valorises the interstitial:

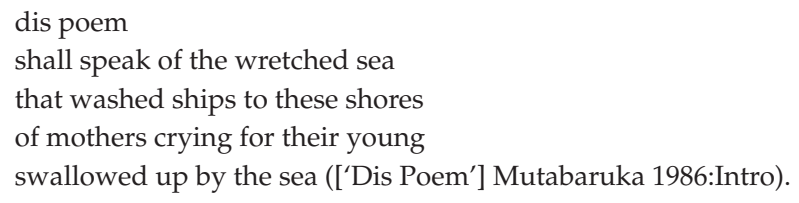

The loaded meanings of 'these shores' in Mutabaruka as in Brathwaite are garnered by the conceptualisation of poetry as orality and a performative memory that requires the personal, physical participation of its readers and audiences as they actively become aware of the hunger for personal connections with an immersive environment.

In X/Self, Brathwaite's Sycorax video style, calibanism and 'stammament' remind us that 'postcolonial speech begins in a stammer' (['Wringing the Word'] Brathwaite 1987:136). He quotes 'Negus', a poem from Islands, as an example of this stammering that is present as the postcolonial agent begins to utilise this new language, in oral and written form. This stuttering is also present in the first version of X/Self's letter:

like de man still mekkin i walk up de slope dat e slide
in black down de whol long curve a de arch
i
pell
ago
long
long
ago
like a
tread
like a
tread
like a
tread
mill
or
mile
stone
or pet
like a pet
like a perpet.
ual plant
or
plantation $([X / S e l f]$ Brathwaite 1987:87).

Brathwaite stretches the 'arch/i/pell/a/go' to one more syllable, but replaces the stammering lines below it with a substantial new section of political critique. This would suggest that as Brathwaite becomes more comfortable with his 'nation language', in the incrementally complicated Sycorax video style, he overcomes the most pronounced stuttering. However, slight 'stammamments' do remain in the poem, 'like I is a some/is a some//is a some-/body body', to remind readers that X/Self (who is an appropriation of Caliban) is not thoroughly versed in his language. There is a deliberate subversion of the canon where the pronoun ' $\mathrm{I}$ ' has always been in upper case in the English language. Equally, the 'arc' of the 'archipellago' redoubles its menace to the centre, endorsing what Edouard Glissant (1999) insists should be the provenance of the Barbadian dub poet and the word: 'forge a new language' and 'propose language as shock, language as antidote, a non-neutral one, through which the problems of the community can be restated'.

In addition, Brathwaite engages poetic ellipses, cataphoric colons and anticipatory commas which result in a novel and innovative lexico-syntactic compression, particularly in the run-on lines characterising the poems. As Shakespeare's The Tempest is re-interpreted and re-appropriated to cast Caliban as a revolutionary progenitor of a new awakening, one engages with a deterritorialised form of 'nation language', a creative re-inauguration of hybridity as a template for a remapped ontological universe, always becoming (Deleuze \& Guattari 1980). This style enables [and ennobles] the African universe to become a bedrock of the mythological, historical, cultural and literary repertoire explored and exploited to nurture an affirmative Barbadian and Caribbean consciousness.

\section{New uses of adversity: Languaging and becoming}

Brathwaite's invocation and experimental appropriation of 'nation language' (Brathwaite 1984) is a significant mediation that destabilises and de-authorises coloniality, inscribing a new 'in-betweenness' that highlights how the subaltern can speak. I have argued consistently that the poet-persona's minted vocabulary and his re-appropriation of canonical texts such as the Bible and Shakespeare's The Tempest inaugurates a meta-discursive enunciation of epistemic possibilities. In embracing the fragmented contours of Barbados and radically privileging the political complicity of Africa in the matrix of slavery, Brathwaite embosses languaging as the primus for problematising identity, belonging and becoming. In the twin enactments of performance and scripting from a fragmented, amnesiac and diasporic world, Brathwaite generates new realms of belonging and becoming (Silberman \& Purser 2016). Polysemy in the various anthologies discussed in this article therefore emerges as a complex interplay of enunciation and emergence, agency and contemplation, subjectivity and restlessness that recuperates the anguish of contact, marginality and creative resistance while at the same time celebrating the plurality of the interstitial self.

\section{Acknowledgements Competing interests}

The author declares that he has no financial or personal relationships which may have inappropriately influenced him in writing this article.

\section{References}

Bhabha, H.K., 1990, 'DissemiNation: Time, narrative and the margins of the modern nation', in H.K. Bhabha (ed.), Nation \& narration, pp. 291-322, Routledge, London. Brathwaite, E.K., 1973, The Arrivants, Oxford University Press, Oxford. 
Brathwaite, E.K., 1977, Mother Poem, Oxford University Press, Oxford.

Brathwaite, E.K., 1984, History of the voice: The development of nation language in Anglophone Caribbean poetry, New Beacon Books Ltd., London.

Brathwaite, E.K., 1986, Nation Language, n.p., Mona, Jamaica.

Brathwaite, E.K., 1987, X/Self, Oxford University Press, Oxford.

Brathwaite, E.K., 1992, Sun Poem, Oxford University Press, Oxford.

Cabral, A., 1973/1982, Return to the source: Selected speeches of Amilcar Cabral, Monthly Review Press, London, New York.

Campbell, H., 1985, Rasta and resistance: From Marcus Garvey to Walter Rodney, Hansib Publishing Limited, London.

Césaire, A., 2014, Return to My Native Land, Archipelago Books, Brooklyn, NY.

Deleuze, G. \& Guattari, F., 1980, A thousand plateaus, transl. B. Massumi, University of Minnesota, Minneapolis, MN.

Gilroy, P., [1993]1999, The Black Atlantic: Modernity and double-consciousness, Verso, London.

Glissant, E., 1999, Caribbean discourse, transl. J. Michael Dash, UP of Virginia, Charlottesville, VA.

Hall, S., 1996, 'Introduction: Who needs "identity"?', in S. Hall \& P. du Gay (eds.), Questions of cultural ildentity, Sage, Thousand Oaks, CA.
Josephs, K.B., 2003, 'Versions of X/Self: Kamau Brathwaite's Caribbean Discourse', Anthurium: A Caribbean Studies Journal 1(1), Article 4.

Masemola, K.M., 2017, Black South African autobiography after Deleuze: Belonging and becoming in self-testimony, Cross/Cultures, 198, Brill, Leiden.

Mutabaruka, 1986, The mystery unfolds, viewed n.d., from https://genius.com

Murphy, R. \& Vinson, J. (eds.), 1970, Contemporary poets of the English language, St. James Press, London.

Rohlehr, G., 1983, 'Between literature and history: A personal encounter', in Transgression, transition, transformation: Essays in Caribbean culture, pp. 338-391, San Juan, Trinidad and Tobago.

Silberman, N. \& Purser, M., 2016, 'Collective memory as affirmation: People-centred cultural heritage', in E. Giaccardi (ed.), Heritage and Social Media Understanding heritage in a participatory culture, pp. 13-29, Left Creek Press, Walnut Creek, CA.

Thurgar-Dawson, C.P.J., 1998, 'The contemporary long poem: Spatial practice in the work of Kamau Brathwaite and Derek Walcott, Ed Dorn and Susan Howe; Robert Kroetsch and Daphne Marlatt', Durham theses, Durham University, viewed 22 February 2018, from http://etheses.dur.ac.uk/1054/

Vettorato, C., 2012, African languages in Baraka, Brathwaite and Nascimento: From Loss to Possession, viewed 04 July 2018, from http://quaderna.org/africanlanguages-in-baraka-brathwaite-and-nascimento-from-loss-to-possession/

Vinson, J. (ed.), 1983, MacMillan great writers student library: Twentieth century poetry, MacMillan Press, Hong Kong. 